\title{
UNILATERAL NASAL OBSTRUCTION CAUSED BY SINO-NASAL NEOPLASTIC LESIONS
}

\author{
Syed Mosaddaque Iqbal and Syed Iqbal Hussain
}

\begin{abstract}
OBJECTIVE: To report pattern of unilateral nasal obstruction caused by sino-nasal neoplasms seen in two teaching hospitals in Sindh, Pakistan.

DESIGN: A case series.

SETTING: Ear, Nose and Throat (ENT) departments of Jinnah Postgraduate Medical Centre, Karachi and People's Medical College, Nawabshah between June 1995 to June 1998.

METHODS: This study included 51 patients who presented with unilateral nasal obstruction persistantly for more than eight weeks. A proforma was designed to note the complaints, pinpoint the cause and look at the outcome of the treatment and prognosis. Thus, a detailed history of patients was undertaken through clinical examination, laboratory investigations e.g. blood profile, urine analysis, radiological (common and special) imaging, biopsy and histopathology.

RESULTS: Neoplastic lesions of the nose and paranasal sinuses were found in $\mathbf{5 1}$ patients. This included $16(31.37 \%)$ females and $35(68.62 \%)$ males with an average age of 37 years. Benign lesions were $19(37.25 \%)$ and $32(62.75 \%)$ were malignant including single case of schwanoma, two cases of squamous papilloma and three patients with fibrous dysplasia while inverted papilloma was seen in six and nasopharyngeal angiofibroma in seven patients. Commonest malignant lesion was squamous cell carcinoma seen in 30 (58.82\%) patients. Maxillary sinus was involved in $\mathbf{3 0}$ cases and 2 of them were arising from the ethmoid sinus and nasal cavity, and were found to be adenocarcinoma. For benign lesions, wide surgical approach was adopted and except one case of inverted papilloma which reccurred, rest were cured completely. Radical and oncologically sound surgical resection combined with radiation therapy remained the treatment of choice for all the malignant lesions. Local recurrence was seen in two cases. Only one patient died after 8 months due to distant metastasis. Two patients were lost to follow up after 25 months.

CONCLUSION: Neoplastic lesions especially the benign tumors, promptly treated via wide surgical approach, mostly cure the lesion with negligible complication or no recurrence. Malignant lesions of the nose and sinuses are very often diagnosed in advanced T-stages (intracranial or intraorbital extentions) due to non-specific symptoms and have a poor overall prognosis even in the advances in surgical techniques, radiation therapy and new chemotherapeutic agents.
\end{abstract}

KEY WORDS: Neoplasm. Nose. Sinus. Malignancy.

\section{INTRODUCTION}

Patients in Ear, Nose and Throat (ENT) out patients clinics often present with unilateral nasal obstruction, which is clinically challenging on account of differences in underlying etiology. All such patients should be screened for sino-nasal neoplasms, which are rare but when symptomatic are usually at an advanced stage with intraorbital or intracranial extentions. ${ }^{1}$ These clinical presentations may be indistinguishable from benign and inflammatory disorders, thereby, posing diagnostic and therapeutic challenges. Neoplastic lesions of the nose and sinuses are rare i.e. less than $3 \%$ of all ENT malignancies and less than $1 \%$ of all malignant lesions. ${ }^{2}$ These malignancies are seen in $5^{\text {th }}-7^{\text {th }}$ decades, commonly in males with a 2:1 male female ratio. $^{3}$

Nasal cavity is a site for both benign lesions e.g. inverted papilloma and malignant tumors like squamous cell carcinoma. ${ }^{4}$ Para-nasal sinus neoplasms are mostly malignant, and again the squamous cell carcinoma is mostly seen. Maxillary sinus is most commonly involved followed by the nasal cavity and then ethmoid sinus. Initiating factors are occupational exposures e.g. nickel, chromium, isopropyl oils, volatile hydrocarbons, organic fibers found in the wood, shoe and textile industry. ${ }^{5}$ In addition, human papilloma virus can be a co-factor. ${ }^{6}$ Benign neoplasms causing unilateral nasal obstruction are squamous papilloma arising from the 
nasal vestibule, inverted papilloma commonly seen between $4^{\text {th }}-5^{\text {th }}$ decade, arises from the lateral wall and grows into the nose and sinuses. ${ }^{7}$ Haemangioma of capillary type presents on the nasal septum as a bleeding polyp. ${ }^{8}$ Fibroma is rare, however, osteoma commonly arises from the frontal sinus and rarely from the ethmoid or maxillary sinus, between $15-35$ years of age. ${ }^{9}$ Fibrous dysplasia is commonly seen before the age of 20 years and affects maxilla and mandible with ground glass appearance on X-ray. ${ }^{10}$ Juvenile nasopharyngeal angiofibroma is a highly vascular bengin tumor of the nasopharynx and occurs between $8-17$ years of age, exclusively in males. ${ }^{11}$

Among the malignant neoplasms, $85 \%$ are squamous cell carcinoma ${ }^{12}$, of which $60 \%$ are seen in the maxilla, $30 \%$ in the nasal cavity, while $10 \%$ involve the ethmoid sinus. Adenocarcinoma is commonly present in wood workers and $5-20 \%$ of malignant neoplasms of sino-nasal region commonly involve the ethmoid sinus. ${ }^{13}$ Melanoma is $3 \%$ of all neoplasms ${ }^{14}$ and olfactory neuroblastoma arises from the olfactory bulb. Nasopharyngeal tumors are usually seen in $7^{\text {th }}$ or $8^{\text {th }}$ decade commonly in males and $60 \%$ are squamous cell carcinoma followed by adenocarcinoma and nonHodgkin's lymphoma in $10 \%$ cases, while lymphoepithelioma may also be seen. ${ }^{15}$ Sarcomas are rare and include Osteo, Chondro, Fibro or Rhabdomyosarcoma present in children and diagnosed at biopsy. Metastatic tumors may come from kidney ${ }^{16}$, lungs and the breast. ${ }^{17}$

\section{PATIENTS AND METHODS}

This is a descriptive study of 51 patients, conducted from June 1995 to June 1998 at the ENT departments of Jinnah Postgraduate Medical Centre, Karachi and People's Medical College, Nawabshah - Sindh, where patients are referred from all over the country especially from Sindh and Balochistan provinces.

Those patients who presented with unilateral nasal obstruction persistently for the previous 8 weeks or more, instead of repeated therapy were included in study. A standard proforma was designed to collect data of each participant. In all selected patients, a detailed history, routine investigations like blood CP and ESR, X-rays of chest, para nasal sinuses and nasopharynx were carried out. ECG, blood sugar, blood urea, serum creatinine and serum electrolytes were advised in patients when required. CT scan was done in cases where site and extent of the lesion, intracranial involvement and areas of bone destruction were suspected, while MRI and Angiography were done according to the need. All the patients were evaluated for any systemic illness like diabetes mellitus, hypertension, pulmonary and cardiovascular diseases. Any patient found with systemic problem was referred to concerned specialist. Biopsy and histopathology were carried out in all cases of sinonasal mass (both pre and post-operative) for final diagnosis.

\section{RESULTS}

In this study, neoplastic lesions of the nose and sinuses were found in 51 patients. There were 16 females and 35 males with age ranging from 11 to 65 years. Out of 51 patients, six had external nasal deformity. Proptosis was seen in three patients, while six had palatal buldging. Hypertelorism was found in three patients and eight had cheek swellings. Loss of vision was found in one patient only and 38 patients had recurrent nasal bleeding. Palpable neck nodes were seen in three and polypoidal mass was present in most of the cases (Table I). X-ray paranasal sinuses showed opaque maxillary sinus and ethmoid sinus in 36 and 9 cases respectively. CT scan was done in most of the cases. Angiography and preoperative embolization were performed in all seven cases of Juvenile nasopharyngeal angiofibroma. MRI was done in one patient only. Biopsy and histopathology were done in 44 cases while for angiofibroma, it was done after surgical excision of the mass. Benign lesions were found in 19 patients and 32 were malignant. Benign included two cases of squamous papilloma, single case of schwanoma and three of fibrous dysplasia. Meanwhile, inverted papilloma was seen in six and nasopharyngeal angiofibroma in seven patients.

Among the malignant lesions, squamous cell carcinoma was found in 30 patients arising from the maxillary sinus and only two cases of adenocarcinoma arising from the ethmoid and nasal cavity. Twentynine patients were diagnosed when they were in stage III, while 3 were in stage II. Only three patients had palpable submandibular lymph nodes. Involvement of the anterior skull base, infratemporal fossa and orbital erosion was not seen. Wide surgical excision of benign lesions was completed through lateral rhinotomy in eleven patients and Weber Fergusson was carried out in seven including one case of recurrent inverted papilloma and six patients of Juvenile nasopharyngeal angiofibroma. Midface degloving approach was performed in a child having Juvenile nasopharyngeal angiofibroma. For 32 cases of sinonasal malignancies, Weber Fergusson was carried out in 30 patients and in two cases where the 
lesion was limited to nasal cavity, lateral rhinotomy was the treatment of choice. Radical neck dissection (ipsilateral) was performed in 3 and supra-omohyoid neck dissection was done in 28 patients (Table II). However, radical and oncologically sound surgical resection combined with adjuvant radiation therapy remains the treatment of choice.

Complications were minimal like post-operative pyrexia, oedema, crusting and bleeding, and were easily controlled by usual measures. Scars of lateral rhinotomy and Weber Fergusson were cosmetically acceptable. Thus, in this study, all the benign lesions were completely cured via wide surgical excision except single case of inverted papilloma which recurred after 13 months. Only one case of adenocarcinoma died due to distant metastasis within 8 months while two cases were lost during follow-up after 25 months (Table III).

TABLE I:

BASELINE CHARACTERISTICS OF THE PATIENTS ALONG WITH SIGNS AND SYMPTOMS

\begin{tabular}{|c|c|c|}
\hline $\begin{array}{c}\text { PARAMETERS } \\
\text { AND CHARAC- } \\
\text { TERISTICS }\end{array}$ & $\begin{array}{l}\text { NUMBER } \\
\text { OF } \\
\text { PATIENTS }\end{array}$ & $\begin{array}{c}\text { PRECENTAGE } \\
\%\end{array}$ \\
\hline $\begin{array}{l}\text { GENDER } \\
\text { Male } \\
\text { Female }\end{array}$ & $\begin{array}{l}35 \\
16\end{array}$ & $\begin{array}{l}68.62 \\
31.37\end{array}$ \\
\hline $\begin{array}{l}\text { AGE (in years) } \\
11-30 \\
31-50 \\
51-65\end{array}$ & $\begin{array}{c}6 \\
13 \\
32\end{array}$ & $\begin{array}{l}11.76 \\
25.49 \\
62.74\end{array}$ \\
\hline $\begin{array}{l}\text { DURATION OF } \\
\text { SYMPTOMS } \\
\text { (in days) } \\
60-90 \\
90-120 \\
120-150\end{array}$ & $\begin{array}{c}2 \\
29 \\
20\end{array}$ & $\begin{array}{c}3.92 \\
56.86 \\
39.21\end{array}$ \\
\hline $\begin{array}{l}\text { SYMPTOMS AND } \\
\text { SIGNS } \\
\text { Nasal blockage } \\
\text { Nasal mass } \\
\text { Epistaxis } \\
\text { Nasal discharge } \\
\text { Cheek swelling } \\
\text { Palate swelling } \\
\text { External definty } \\
\text { Telecanthus } \\
\text { Proptosis } \\
\text { Loss of vision } \\
\text { Neck gland }\end{array}$ & $\begin{array}{l}51 \\
47 \\
38 \\
25 \\
8 \\
6 \\
6 \\
3 \\
3 \\
1 \\
3\end{array}$ & $\begin{array}{r}100.0 \\
92.15 \\
74.50 \\
49.01 \\
15.68 \\
11.76 \\
11.76 \\
5.88 \\
5.88 \\
1.96 \\
5.88\end{array}$ \\
\hline
\end{tabular}

TABLE II:

DIAGNOSTIC TOOLS AND SURGICAL APPROACHES ADOPTED

\begin{tabular}{|l|c|c|}
\hline $\begin{array}{l}\text { DIAGNOSIS AND } \\
\text { TREATMENT }\end{array}$ & $\begin{array}{c}\text { NUMBER } \\
\text { OF CASES }\end{array}$ & $\begin{array}{c}\text { PERCENTAGE } \\
\%\end{array}$ \\
\hline $\begin{array}{l}\text { INVESTIGATION } \\
\text { X-ray PNS show- } \\
\text { ing bony erosion } \\
\text { Biopsy done (pre- } \\
\text { operative) }\end{array}$ & 33 & 64.70 \\
$\begin{array}{l}\text { CT scan } \\
\text { Angiography and } \\
\text { embolization }\end{array}$ & 44 & 86.27 \\
MRI & 49 & 96.07 \\
\hline $\begin{array}{l}\text { SURGICAL } \\
\text { PROCEDURE } \\
\text { Weber Fergusson } \\
\text { Lateral Rhinotomy } \\
\text { Mid-Face }\end{array}$ & 1 & 13.72 \\
Degloving & 13 & 1.96 \\
Radical Neck & 1 & 72.54 \\
Dissection & & 25.49 \\
Selective Neck & 3 & 1.96 \\
Dissection & 29 & 5.88 \\
\hline
\end{tabular}

TABLE III:

TREATMENT MODALITY OFFERED, THEIR COMPLICATIONS AND OUTCOMES

\begin{tabular}{|c|c|c|}
\hline $\begin{array}{l}\text { TREATMENTI } \\
\text { OUTCOME }\end{array}$ & $\begin{array}{l}\text { NUMBER } \\
\text { OF CASES }\end{array}$ & $\begin{array}{c}\text { PERCENTAGE } \\
\%\end{array}$ \\
\hline $\begin{array}{l}\text { MODALITY OF } \\
\text { TREATMENT } \\
\text { Surgery } \\
\text { Surgery and } \\
\text { Radiotherapy } \\
\text { (post-operative) }\end{array}$ & $\begin{array}{l}51 \\
32\end{array}$ & $\begin{array}{l}100.0 \\
62.74\end{array}$ \\
\hline $\begin{array}{l}\text { POST- } \\
\text { OPERATIVE } \\
\text { COMPLICATION } \\
\text { Infection } \\
\text { Stitch abscess } \\
\text { Crusting }\end{array}$ & $\begin{array}{c}6 \\
3 \\
10\end{array}$ & $\begin{array}{c}11.76 \\
5.88 \\
19.60\end{array}$ \\
\hline $\begin{array}{l}\text { FOLLOW-UP } \\
\text { Disease free } \\
\text { survival } \\
\text { Residual disease } \\
\text { Died of disease } \\
\text { Lost to follow-up }\end{array}$ & $\begin{array}{c}34 \\
14 \\
1 \\
2\end{array}$ & $\begin{array}{c}66.66 \\
27.45 \\
1.96 \\
3.92\end{array}$ \\
\hline
\end{tabular}




\section{DISCUSSION}

Nasal obstruction is one of the most common complaints, which may be persistent or transient, unilateral or bilateral. Early diagnosis and adequate treatment is the gold standard because different pathologies of the nose, nasopharynx and paranasal sinuses can present only with nasal obstruction. In this study, 51 cases were analysed where unilateral nasal obstruction presented persistently for at least a specified period of 8 weeks or more. Laboratory investigations like complete blood count and urine D/R are essential for the evaluation of general state of patient's health, while diabetes, anaemia and neutropenia were found in a few cases. Radiological investigations were routinely done like $X$-ray chest, $X$ ray PNS (water's view) as they are important for showing bony erosions in cases of carcinoma of the sino-nasal region. ${ }^{18}$ Antral sign or anterior bowing of posterior wall of maxilla and posterior bowing of pterygoid plate become evident in nasopharyngeal angiofibroma. $^{19}$ Flexible nasoendoscopy has been a useful tool for examination of nose, paranasal sinuses and nasopharynx. C.T. scanning has been very useful and is mandatory in most of the cases to know the site and extent of pathology and subsequent response to the treatment. ${ }^{20}$ Contrast enhancement of C.T. scan is needed in suspected cases of intracranial involvement. It is also needed in vascular tumor like nasopharyngeal fibroma or meningiomas and recommended in the assessment of patient in whom the sinus disease with bone destruction had been identified on conventional radiographic examination. ${ }^{21}$ MRI or magnetic resonance imaging, which is noninvasive technique was done only when needed. MRI is more sensitive than C.T. scan in demonstrating the inflammatory changes in the sinus mucosa although false positive and false negative scan are not unusual. $^{22}$ Biopsy was taken in all cases of mass in the nasal cavity or sinuses, but nasopharyngeal Angiofibroma was diagnosed clinically and preoperative angiography and embolization was done to reduce the peroperative bleeding. In sino-nasal pathologies, biopsy was done via intra -nasal route, but when a mass was in the maxillary antrum, intranasal antrostomy was the route for biopsy. Biopsy can also be done via sinoscope and all masses shall be send for histopathological examination. ${ }^{23}$ Angiography acts in a double way. It may define the circulatory pattern of the mass and also a useful mean in controlling the per-operative bleeding by pre-operative embolization. Surgery is the treatment of choice for angiofibroma, while radiation and chemotherapy are reserved for recurrent, inoperable and cases with intracranial extention. ${ }^{24}$ In this study, six patients of Angiofibroma were treated via Weber Fergusson approach, which is an extension of lateral rhinotomy incision. The wide exposure offered by this approach ensures that the tumour mass is freed from its surrounding relations without breaking it into pieces and with minimum blood loss. ${ }^{25}$ One patient was a young boy in whom Mid-face degloving was done. This technique obviates visible scarring and allows adequate exposure to the nasal complex, nasopharynx and mid third of the face. ${ }^{26}$ All six patients of inverted papilloma were males with ages between 28-52 years. Five patients were approached via lateral rhinotomy and complete excision of the tumour. One patient with marked cheek swelling was approached via Weber Fergusson and total maxillectomy was done as tumor had involved the whole maxilla. ${ }^{27}$ Thirty-two cases of malignancy of nose and paranasal sinuses were recorded and 30 of them were squamous cell carcinoma of maxilla and nose including two cases of adenocarcinoma. All of them were males of $5^{\text {th }}$ and $6^{\text {th }}$ decade but one case with adenocarcinoma was a young male of about 32 years from Balochistan and was working in a wood factory. Patients of squamous cell carcinoma presented with unilateral nasal obstruction, cheek swelling and epistaxis while one case with adenocarcinoma presented with right cheek swelling, unilateral nasal obstruction, proptosis, telorism, nasal mass and ipsilateral loss of vision. Among the sinonasal tumours, squamous cell carcinoma was the commonest and maxilla was the commonest site. ${ }^{28}$ The majority of patients of sino-nasal cancer presented in $5^{\text {th }}$ and $6^{\text {th }}$ decade with male predominance, usually presented late ${ }^{29}$ and belonged to lower socio-economic group. In case of unexpected facial pain with erosion or destruction of maxilla which is confirmed by C.T. scan, malignant growth should always be suspected. Combined surgery and radiotherapy yields good results ${ }^{30}$ and chemotherapy is palliative. Facial defects after radical maxillectomy and orbital exentration reconstruction are done with the help of orthodontist ${ }^{31}$, which we required in two cases in this study.

\section{CONCLUSION}

Unilateral nasal obstruction is a common presentation in our set up. It may be associated with sore throat, epistaxis, halitosis, referred otalgia, fatigue and abnormal facial development in children. Neoplastic lesions like benign tumors, once diagnosed should be promptly treated via wide surgical approach, for complete cure with minimal or no recurrence. Malignant tumours of sino-nasal region e.g. squamous cell carcinoma are rarely diagnosed in stage I and II. Radical surgery with adjuvant radiotherapy usually 
follows a better prognosis. Thus, malignant lesions are mostly diagnosed in advanced T-stages due to lack of specific symptoms, and have a poor overall prognosis even with advance surgical techniques, radiation therapy and new chemotherapeutic agents. Local recurrence is a big problem due to complex anatomy of the region. For improvement in the treatment outcomes of the sino-nasal malignancies, multicenteric trails are necessary.

\section{REFERENCES}

1. Myers LL, Oxford LE. Differential diagnosis and treatment options in paranasal sinus cancer. Surg Oncol Clin N Am. 2004;13(1):167-86.

2. Euteneuer S, Sudhoff H, Bernal-Sprekelsen M, et al. Malignomas of the nasal cavity and the paranasal sinuses: clinical characteristics, therapy and prognosis of different tumour types. Laryngorhinotologie. 2004;83(1):33-9.

3. Zbaren P, Richard JM, Schwaab G, et al. Malignant neoplasms of the nasal cavity and paranasal sinuses. Analysis of 216 cases of malignant neoplasms of nasal cavity and paranasal sinuses. HNO. 1987; 35(6):246-9. [Article in German)

4. Buchanan G. Tumours of the nose and sinuses; a clinicopathological study. JLC. 1998; 84: 685.

5. Hadfield E. Tumours of nose and sinuses in relation to wood workers. J Laryngol. 1989; 33: $417-422$.

6. Wu TC, Trujillo JM, Kashina HK, et al. Association of human papilloma virus with nasal neoplasia. Lancet. 1993; 341(8844):522-524.

7. Dahl M, Schaffer S, Wisdom GS. Inverting papilloma of the nose and paranasal sinuses. J LA State Med Soc. 2003; 155(5):235-7.

8. Sheppard LM, Mickleson SA. Haemangiomas of the nasal septum and paranasal sinuses. Henry Ford Hosp Med J.1990; 38(1): 25-7.

9. Dispenza C, Martines F, Dispenza F, et al. Frontal sinus osteoma complicated by pelpebral abscess. Acta Otorhinolaryngol Ital. 2004;24(6):357-60.

10. Simovic S, Klapan I, Bumber Z, et al. Fibrous dysplasia in paranasal cavities. ORL J Otorhinolaryngol Rehet Spec. 1996;58(1): 55-8.

11. Beham A, Beham-Schmid C, Regauer S, et al. Nasopharyngeal angiofibroma: true neoplasm or vascular malformation. Adv Anat Pathol. 2000; 7 (1): 36-46.

12. Gullane PJ, Conley J. Carcinoma of the maxillary sinus. J Otolaryngol.1983,12:141-145.

13. Orvidas LJ, Lewis JT, Weaver IL, et al. Adenocarcinoma of the nose and paranasal sinuses: a retrospective study of diagnosis, histologic characteristics and outcomes in 24 patients. Head Neck. 2005; 27(5): 370-5.

14. Thompson AC, Morgan DA, Bardley PJ. Malignant melanoma of the nasal cavity and paranasal sinuses. Clin Otolaryngol. 1993;18(1): 34-36.

15. Sanguineti G, Geara FB, Garden AS, et al. Carcinoma of the nasopharynx treated by radiotherapy alone: determinants of local and regional control. Int $\mathrm{J}$ Radiat Oncol Biol Phys.1997;37(5): 973-4.

16. Lee $\mathrm{HM}$, Kang $\mathrm{HJ}$, Lee $\mathrm{SH}$. Metastatic renal cell carcinoma presenting as epistaxis. Eur Arch Otorhinolaryngol. 2005; 262(1): 69-71.

17. Marchioni D, Monzani D, Rossi G, et al. Breast carcinoma metastases in paranasal sinuses, a rare occurrence mimicking a primary nasal malignancy: case report. Acta Otorhinolaryngol Ital. 2004; 24(2): 87-91.

18. Sherman IW, Phillips DE. Interpretation of maxillary sinus radiographs in children. Arch Otolaryngol Head and Neck Surg. 1991; 105: 541-543.

19. Jamal MMN. Imaging and management of angiofibroma. Eur Arch Otorhinolaryngol. 1994; 251(4): 241-5.

20. Hong $Y$, Liang $Z$, Lin $P$. The diagnosis and treatment of nasopharyngeal angiofibroma. Lin Chuang Er Bi Yan Hou Ke Za Zhi. 2004; 18(1): 33-4.

21. Rushton VE, Theaker ED, Whitehouse RW, et al. Radiological appearance of clinical inflammatory sinus disease with bone destruction. The significance of contrast enhancement. Dento Maxillo Facial Radiol. 1994; 23: 33-36.

22. Cooke LD, Hadley DM. MRI of the paranasal sinuses, incidental abnormalities and their relationship to symptoms. J Laryngol Otol. 1991;105:278-281.

23. Alun-Jones T, Hill J, Leighton SC, et al. Is routine histological examination of nasal polyps justified?. Clin Otolaryngol. 1990; 15(3): 217-219.

24. Paris J, Guelfucci B, Moulin G, et al. Diagnosis and treatment of juvenile nasopharyngeal angiofibroma. Eur Arch Otorhinolaryngol. 2001;258(3):120-4. 
25. Fagan JJ, Synderman $\mathrm{CH}$, Carrau $\mathrm{RI}$, et al. Nasopharyngeal angiofibromas: selecting a surgical approach. Head Neck. 1997; 19(5):391-9.

26. Metheetraairut C, Thongyai K. Mid-facial degloving surgical approach: experience at Siriraj hospital. J Med Assoc Thai. 2003; 86(11):1024 - 32.

27. Nwaorgu OG, Onakoya PA. Inverted papilloma of the nose and paranasal sinuses: a fifteen year review. Afr J Med Sci. 2002; 31(3):191-4.

28. Spiro JD, Soo KC, Spiro RH. Squamous carcinoma of the nasal cavity and paranasal sinuses. Am J Surg. 1989; 158(4): 328-32.
29. Avarez I, Suarez C, Rodrigo JP, et al. Prognostic factors in paranasal sinus cancer. Am J Otolaryngol. 1995;16(2):109-14.

30. Jansen EP, Keus RB, Hilgers FJ, et al. Does the combination of radiotherapy and debulking surgery favor survival in paranasal sinus carcinoma? Int J Radiat Oncol Biol Phys. 2000; 48(1): 27-35.

31. Katz TS, Mendenhall WM, Morris CG, et al. Malignant tumors of the nasal cavity and paranasal sinuses. Head Neck. 2002;24(9):821-9.

AUTHOR AFFILIATION:

Dr. Syed Mosaddaque Iqbal (Corresponding Author) Assistant Professor E.N.T

Jinnah Medical and Dental College

22-23 Shaheed-e-Millat Road, Karachi -74000.

Dr. Syed Iqbal Hussain

Assistant Professor E.N.T

People's Medical College

Nawabshah - Sindh. 